\title{
Review of Michel de Vroey's A history of macroeconomics from Keynes to Lucas and beyond. New York: Cambridge University Press, 2016, 429 pp.
}

\author{
MiCHAËL AsSOUS \\ University of Lumière-Lyon 2, TRIANGLE
}

Michel De Vroey's A history of macroeconomics from Keynes to Lucas and beyond is an important contribution to the history of economic thought. Standing upon the shoulders of two giants of the twentieth century, John Maynard Keynes and Robert Lucas, De Vroey sets out a clear-cut narrative. The modern history of macroeconomics is the result of a two-step process. The first step corresponds to the transition from Keynes's actual writing in his General theory (1936) to Keynesian macroeconomics, which roughly occurred between the 1940s to the 1970s (sections 1 to 8, or part I). The second step corresponds to the era of "DSGE macro", i.e., dynamic stochastic general equilibrium, which started in the mid-1970s with the "Lucasian revolution" and culminated in the 2000s with the new neoclassical synthesis (sections 9 to 18 , or part II).

With the primary ambition of helping economists and teachers "ponder the origin of the kind of modeling with which they are familiar" (p. xiii), De Vroey endorses the canonical textbook reading of the history of macroeconomics - a reading that he himself argued for in a long series of papers - which highlights models developed by the main protagonists of both Keynesian and classical approaches. This list includes models of Nobel Prize-winning economists (e.g., John Hicks, Franco Modigliani, Laurence Klein, Edmund Phelps, Milton Friedman) as well as new classical economists (e.g., Robert Lucas, Finn Kydland, and Edward Prescott) and new Keynesians (e.g., Joseph Stiglitz and Georges Akerlof), among many others. Undoubtedly, any economist who wants to learn more about the theoretical connections between these models will be enthralled with the book.

However, by sticking to an "official" account of the development of macroeconomics, De Vroey limits himself. Because his account pays attention to logical transitions from one model to another, it neglects authors and groups of scholars whose impact has been retroactively 
marginalized. Yet, revisiting these authors may prove to be fruitful. While they may be considered marginal when compared to canonical authors, such authors left undeniable marks in the development of mainstream macroeconomics. I do not mean that De Vroey's analysis is questionable because of subject matter, which-for instance-chooses not to discuss developments in applied economics or heterodox economics. Rather, by paying more attention to historical developments, the book would have provided a more complete picture of macroeconomic development.

Three examples based on recent works on the history of macroeconomics can help make that point clear. I do not aim to be exhaustive here, but only to draw attention to elements that, in my opinion, would have dramatically helped complement the narrative. The first example relates to the emergence of macroeconomics in the context of the Cowles Commission in the United States, the second brings us back to the notion of neoclassical synthesis in the 1960s, and the third has to do with the development of the new neoclassical synthesis. In these three cases, I show that a broader historical account sheds a new light on the development of macroeconomics.

De Vroey's reading of the "first era" of macroeconomics is defined by Keynesians who challenged the core concepts of Keynes with several modeling strategies. Keynes's attempt to prove the existence of an equilibrium with involuntary unemployment, under the assumption that wage-rigidity was not responsible for it, touched off a long theoretical controversy. The first generation of Keynesian economists-led by Hicks, Modigliani, and Klein-admitted that Keynes had failed in his enterprise and argued that involuntary unemployment was, in fact, due to wage rigidity. This recognition became the corner stone of Keynesian macroeconomics embedded in the IS-LM model. A second generation, including Patinkin, Leijonhuvfud, and Clower, launched new lines of research by questioning the wage rigidity hypothesis which eventually led to the development of disequilibrium explanation of involuntary unemployment.

An historical account shows that these two lines of research originate in debates that took place at the Cowles Commission in the early 1940s under the guidance of Oskar Lange, who aimed at clarifying the consistency of Keynes's analysis with the help of Walrasian theory, a theoretical corpus he came to master when debating market socialism. More precisely, the central issue was whether one could prove, in this 
framework, the existence of an equilibrium that permits involuntary unemployment. As required by 'Walras's law', a term coined by Lange, when considering any particular market, if all other markets in an economy are in equilibrium, then that specific market must also be in equilibrium. Any macroeconomic equilibrium thus logically implies that all markets clear. Keynesian equilibrium is no exception. It is by definition that an equilibrium entails that all markets clear. What Keynes called 'involuntary unemployment' thus refers to a situation in which the employment level, for any given level of money wage, is not maximum; or, put differently, an equilibrium in the labor market occurs in the horizontal part of infinitely elastic labor supply curves. Only then Keynesian macroeconomic equilibrium is compatible with the clearing of all markets represented at the intersection between supply and demand curves and the existence of involuntary unemployment or what Lange labels underemployment.

It is precisely that interpretation elaborated at the Cowles Commission in collaboration with economists like Jacok Marshak, Jacob Mosak, and Leonid Hurwicz, that Modigliani, in his famous 1944 Econometrica paper, suggested to compare to Keynesian and classical analyses. The division between Keynes and the classics would hence be based on two conceptions of the functioning of the labor market. The field of Keynesian economics would pertain to the short-term; featured by rigid money wages and infinitely elastic supply curves, while the field of classical economics would pertain to the long-term, featured by flexible money wages. Involuntary unemployment would thereby result from high rates of interest, which are due to a high ratio of nominal quantity of money to fixed nominal wage.

Though Lange was the one who suggested that interpretation, he did not forcefully argue for it. In his 1944 Cowles monograph, in reference to Hicks (1939) and Samuelson (1941), Lange argued that Keynes chose the wrong battleground, a point quickly taken up by Patinkin during his stay at Cowles. Equilibrium analyses and comparative statics are not the best tools for addressing macroeconomic issues. Based on this observation, Lange made two arguments. The first asserted that stationary states are full employment equilibria. The second that the excess supply of labor must cause money wages to decline, but also, that, under depression, employment may not increase. Full employment equilibria may thus be unstable. In this context, Lange concluded that one can demonstrate Keynes's claim that a "trap" might exist from 
which the economy could not be rescued; even though, low wage and price levels are relevant. As to that last point, he was aware that declining money wage rates are (potentially) unfavorable to aggregate demand. Even if this did not succeed in eliminating unemployment, one might not be justified in declaring a situation in which money wages and prices are persistently falling an equilibrium. But perhaps he did not insist upon it strongly enough, for the subsequent theoretical argument in the 1950s mostly focused on the statics of alternative stable wage levels (Modigliani) and later on the stability of full employment (Patinkin). The issue was by no means dead in the late 1960s when 'full employment' became the 'natural rate' of unemployment. Once again, with the works of Friedman, it is alleged that the private market economy can and will, without aid from government policy, steer itself to full employment equilibrium.

Lange's stance, though marginalized, never completely vanished. Leijonhuvfud (1973) and Tobin (1975) precisely strived to revive it with the notion of the "corridor of stability", with which they argued that the economy may be locally stable but globally unstable. Currently, it is the basis for a policy of letting the recession run its course when the economy is close to the stationary state in confidence that in a relatively short time, equilibrium will be restored at full employment. Conversely, when the economy is pushed out of the corridor, deflation may be dangerous and destabilizing.

Besides the roads taken by Keynesian macroeconomists that are explored by De Vroey, one can see that Lange's route, though much less followed, also influenced Keynesian debates from the start. Doubtless, it would have greatly helped De Vroey to shed new light on developments in Keynesian economics and in complementing his summary displayed in the form of a decision tree given in Box O.1 (p. xvii).

The second lacking historical account refers to the neoclassical synthesis. De Vroey's History attempts to give a clear account of the content of the neoclassical synthesis introduced by Samuelson in the third edition of Economics (1955) in order to describe a consensus in the American economic community whereby $90 \%$ of its members adhered to the views of "[m]odern theories of income determination" [Keynesian] and "older economics" [classical] (Samuelson 1955, p. 212). As De Vroey explains, "in this edition of his textbook, Samuelson used the expression time and again, yet in a loose, almost metaphorical way, without clarifying its content" (p. 46). According to De Vroey, only Klein (1950) 
and Patinkin (1956) - although neither of them used that terminologygave it a clear content. In particular, Patinkin is credited with providing a synthesis between short period (i.e., in disequilibrium) Keynesian theory and long period Walrasian theory, with Walrasian equilibrium supposedly acting as the center of gravity for Keynesian disequilibrium states.

Because the book has no ambition of providing any detailed historical account of such synthesis, the analysis ends there. Historically, however, it was understood in radical different way (Assous, Dal-pont, and Manseri 2016). If De Vroey is right to say that Samuelson was unclear about the content of the neoclassical synthesis in 1955, it does not mean that he failed to clarify its content later. Returning to it in the 1960s, he argued that the neoclassical synthesis refers to the idea that through judicious government intervention and planning, economists agreed that the economy would behave like a neoclassical growth model. Along these lines, a forthright exposition of the neoclassical synthesis was given in the sixth edition of Economics in which a chapter on new growth theories was introduced for the first time.

Solow, Tobin, and Samuelson crafted growth models in which constant full employment of factors of production (Solow's seventh assumption of his 1956 paper) was assumed (Halsmayer and Hoover, 2016). If proponents of the neoclassical synthesis considered that their growth model was complementary to and not competing with Keynesian analysis, it is because they thought they were relevant in a "managed economy".

Furthermore, the neoclassical synthesis presented an opportunity to address long-run issues without assuming that the economy adjusts 'automatically' towards a state of full employment. If that were the case, assuming government intervention would no more be essential. As Solow made it clear in a letter addressed to Sen October 26th 1964: "To the extent that "neo-classical" describes the belief that a capitalistic economy tends automatically to full employment, I am no neo-classical and neither is James Meade" (Solow 1951-2011 and undated).

Much evidence shows that the neoclassical synthesis supported by most Keynesians in the 1960s was not based on any implicit idea that the economy could eventually adjust to full employment. So, by not addressing what the neoclassical synthesis meant historically, De Vroey is led to ignore it. It is true that this would have meant devoting some 
pages to growth, a topic he deliberately chose to set aside. But without extending the presentation too much, the narrative would have greatly gained insight into the development of macroeconomics.

Let us now turn to the last historical example. De Vroey's canonical reading of the developments in macroeconomics since the 1970s is that new Keynesians challenged Lucas's (1972) policy ineffectiveness result by moving from a flexible price to a sticky price environment. This was what in fact helped spread the rational expectations hypothesis, according to Alan Blinder $(1989,104)$. In the early 1980s, real businesscycles macroeconomists advanced Lucas's flexible price approach with a dynamic general equilibrium model where technological shocks drove the business cycle. The opposition in this period was between this group and some new Keynesians with their static models of price stickiness. When this latter group went to dynamic models, they contributed to the development of DSGE macroeconomics.

This reading illuminates some developments in mainstream macroeconomics in the $1980 \mathrm{~s}$, but there is a potential pitfall in not questioning it. One very important reaction to Lucas was achieved with multiple equilibria models with flexible prices (Assous and Duarte 2017). This started, after Gale's (1973) seminal contribution, with the very model used by Lucas (1972), an overlapping generations model (OLG), and it developed into two strands: first, the deterministic cycles, and, second, sunspots. The OLG model was really a workhorse model in the 1980s that brought together communities of economists with different backgrounds and interests: those general equilibrium theorists wanting to extend their analysis to intertemporal models, monetary economists searching for microfoundations of money demand, and other more eclectic economists not really committed to a single macroeconomic model such as Lucas.

However, there was a clear effort by such endogenous fluctuations economists to analyze the generality of their results. Deterministic cycles, or sunspots, can occur in more general models, and macroeconomists such as Jess Benhabib, Michael Woodford, Roger Farmer, and Timothy Kehoe moved from OLG to infinitely-lived agent models with market imperfections to establish this. Price stickiness was not a major concern of this literature well into the 1990s. An important concern of the Keynesian view on fluctuations of this literature was with the design of policy regimes that could ameliorate inefficiencies, that was also key to Woodford's 2003 book on an economy modeled with 
infinitely-lived agents, price stickiness, and an interest rate rule. And Woodford is not the only important player in the DSGE literature who was involved with the endogenous fluctuations literature-Galí is another. This eventual connection between the endogenous fluctuation literature and DSGE macroeconomics does not receive much attention in De Vroey's book.

Hence, a historical analysis - in addition to shedding light on important modeling strategies and on important historical developments in macro in the 1980s-brings to the fore an important issue related to the emergence of the new neoclassical synthesis. If the readers grant us the case for a richer understanding of the DSGE literature, it is hard not to see the endogenous fluctuations literature as having been very influential on the issue of policy stabilization, and on contributing in particular ways to the spread of the infinitely-lived agent models in mainstream macroeconomics, which do not conflict with the view that other issues that were important to the sunspot literature were marginalized. Unfortunately, these lines, and the consequences of that research, are not really part of the narrative, even if one may say that works by Farmer are mentioned in final chapters.

To conclude, I would like to strongly emphasize that favoring a historical perspective does not mean giving up assessing different modeling strategies or coping with various technicalities. Both approaches complement each other. My point is that it is by combining these two approaches into a single investigation, one may eventually end up with a much deeper understanding. De Vroey's book is certainly a useful book, but more than half the work still remains to be done.

\section{REFERENCES}

Assous, Michaël, and Pedro Garcia Duarte. 2017. Challenging Lucas: from overlapping generations to infinite-lived agent models. Center for the History of Political Economy Working Paper Series 2017-05. https://ssrn.com/abstract=2910531.

Assous, Michaël, Muriel Dal-pont, and Sonia Manseri. 2016. Walking a tight rope: the neoclassical synthesis in action. Paper presented at $16^{e}$ Colloque international de l'Association Charles Gide, Strasbourg, 15 April.

Blinder, Alan S. 1989. Macroeconomics under debate. Ann Arbor: University of Michigan Press.

Gale, David. 1973. Pure exchange equilibrium of dynamic economic models. Journal of Economic Theory, 6 (1): 12-36.

Halsmayer, Verena, and Kevin D. Hoover. 2016. Solow's Harrod: transforming cyclical dynamics into a model of long-run growth. European Journal of the History of Economic Thought, 23 (4): 561-596. 
Hicks, John. R. 1939. Value and capital: an inquiry into some fundamental principles of economic theory. Oxford: Clarendon Press.

Keynes, John. M. 1936. The general theory of employment, interest and money. London: Macmillan.

Klein, Lawrence R. 1950. Economic fluctuations in the United States, 1921-1941. New York: Wiley.

Lange, Oscar. 1944. Price flexibility and employment. Cowles Commission for Research in Economics, Monograph no. 8. Bloomington: Principia Press.

Leijonhufvud, Axel. 1973. Effective demand failures. Swedish Economic Journal, 75 (1): 27-48.

Lucas, Robert E., Jr. 1972. Expectations and the neutrality of money. Journal of Economic Theory, 4 (2): 103-124.

Meade, James E. 1960. A neo-classical theory of economic growth. London: George Allen and Unwin.

Modigliani, Franco. 1944. Liquidity preference and the theory of interest and money. Econometrica, 12 (1): 45-88.

Patinkin, Don. 1956. Money, interest, and prices. New York: Harper \& Row.

Samuelson, Paul A. 1941. The stability of equilibrium: comparative statics and dynamics. Econometrica, 9 (2): 97-120.

Samuelson, Paul A. 1955. Economics: an introductory analysis. 3rd ed. New York: MacGraw-Hill.

Samuelson, Paul A. 1963. A brief survey of post-Keynesian developments. In Keynes' general theory: reports of three decades, ed. Robert Lekachman. London: Palgrave Macmillan, 331-347.

Solow, Robert M. 1951-2011 and undated. In Robert M. Solow Papers. David M. Rubenstein Rare Book \& Manuscript Library, Duke University.

Solow, Robert M. 1956. A contribution to the theory of economic growth. Quarterly Journal of Economics, 70 (1): 65-94.

Swan, T. W. 1956. Economic growth and capital accumulation. Economic Record, 32 (2): 334-361.

Tobin, James. 1975. Keynesian models of recession and depression, American Economic Review, 65 (2): 195-202.

Woodford, Michael. 2003. Interest and prices: foundations of a theory of monetary policy. Princeton: Princeton University Press.

Michaël Assous is full professor of economics at the University of Lumière-Lyon 2. Assous is most noted for his work in the history of macroeconomics with issues surrounding the modelling of (in)stability in Fisher's, Harrod's, Kalecki's, Lange's, Meade's, and Solow's works. In 2012, he was awarded the ESHET (European Society of the History of Economic Thought) young researcher award.

Contact e-mail: <michael.assous@univ-lyon2.fr> 